\author{
Giuseppe Fabrizio TURRISI
}

\title{
Pristaulacus barbeyi (Ferrière, 1933), new to Iberian Peninsula (Hymenoptera Aulacidae)
}

\begin{abstract}
Riassunto: Pristaulacus barbeyi (Ferrière, 1933), nuovo per la Penisola Iberica (Hymenoptera Aulacidae).
Viene riportata per la prima volta la presenza di Pristaulacus barbeyi (Ferrière, 1933) nella Penisola Iberica sulla base di un esemplare raccolto nel Nord della Spagna (Asturias, Castanedo del Monte), conservato presso il Natural History Museum, London.
\end{abstract}

\begin{abstract}
The occurrence of Pristaulacus barbeyi (Ferrière, 1933) in Iberian Peninsula is reported for the first time on the basis of one female specimen collected in North Spain (Asturias, Castanedo del Monte), stored in the Natural History Museum, London.

Resumen: Pristaulacus barbeyi (Ferrière, 1933), nuevo para la Península Iberica (Hymenoptera Aulacidae).

Se cita por primera vez la presencia de Pristaulacus barbeyi (Ferrière, 1933) en la Península Iberica, en base al estudio de una hembra capturada en norte de España (Asturias, Castanedo del Monte) y depositada en el Natural History Museum, London.
\end{abstract}

Key words: Hymenoptera, Aulacidae, Pristaulacus barbeyi, Iberian Peninsula, first record.

\section{INTRODUCTION}

The Evaniomorph family Aulacidae comprises 243 extant species belonging to two genera (Turrisi et al., 2009), Aulacus Jurine, 1807, with 77 species, and Pristaulacus Kieffer, 1900 (including the former Panaulix Benoit, 1984), with 166 species. Both genera are represented in all zoogeographic regions, except Antarctica, and Aulacus not known from Afrotropics (Kieffer, 1912; Hedicke, 1939; Smith, 2001; Turrisi, 2004; Turrisi et al., 2009). In the Palaearctics, 32 species have been recorded so far, 7 Aulacus and 25 Pristaulacus (Turrisi, 2007, 2011; Turrisi et al., 2009; Turrisi \& Konishi, 2011; Turrisi \& Watanabe, 2011), of which only four presently recorded from Iberian Peninsula (Turrisi, 2007).

Aulacids are parasitoids of wood-boring Hymenoptera (Xiphydriidae) and especially Coleoptera (mostly Cerambycidae and Buprestidae) employing a koinobiont endophagous strategy (Skinner \& Thompson, 1960; Deyrup, 1984; Jennings \& Austin, 2004). Due to this particular biology, aulacids are not easily observed in their natural habitats and they are not frequently collected by most of the usual collecting methods. As consequence, many species are known from a few specimens or only one.

The present note deals with the record of an interesting Pristaulacus-species which has been resulted new to Iberian Peninsula.
Pristaulacus barbeyi (Ferrière, 1933) (Figs. 1-7)

Odontaulacus Barbeyi Ferrière, 1933: 141 (, §̂).

Odontaulacus barbeyi: Hedicke, 1939: 21.

Pristaulacus barbeyi: Smith, 2001: 279; Turrisi, 2007; Turrisi et al., 2009.

Material eXAmined. 19 labelled: Monte Castanedo, Laurea, Spain/Exp. 683, Date 13-15.9,1969, Frank Wilson/Sp III/C.I.E. Coll. A. 3399 (Natural History Museum, London).

The locality mentioned in the original label must be correctly intended as Castanedo del Monte, in Asturias, North Spain, about 500 m a.s.1.

IDENTIFICATION. For detailed descriptions of Pristaulacus barbeyi see Ferrière (1933) and Turrisi (2007). It is a small to medium sized Pristaulacus-species, with length of the body (excluding ovipositor for 9 ) of 6.7$11.8 \mathrm{~mm}$ and fore wing length of 5.1-8.1 $\mathrm{mm}$; the ovipositor length is $1.3 \mathrm{x}$ fore wing length in the holotype, but it is variable among the specimens from Turkey (Turrisi, 2007). It is readily distinguished by the narrow occipital carina, the shape of the lateroventral margin of pronotum, rounded and without toothlike processes (Fig. 5), the inner margin of the tarsal claw bearing two tooth-like processes (Fig. 6), and the short and stocky petiole (Fig. 5). Among the Palaearctic Pristaulacus it is most similar to the Eastern Palaearctic P. kostylevi (Alekseyev, 1986), but it could 


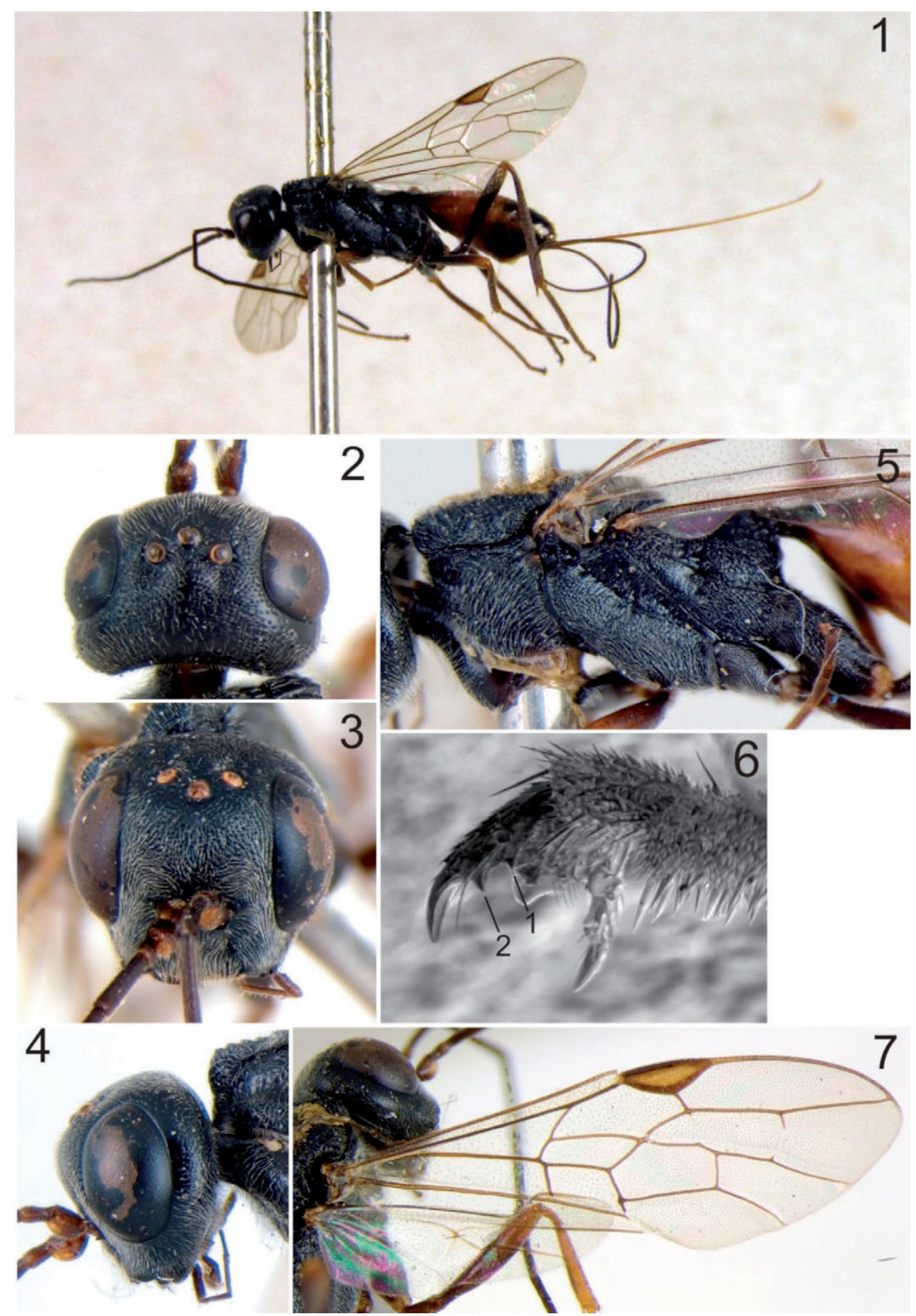

Figs. 1-7. Pristaulacus barbeyi (Ferrière, 1933) 9 from Spain (Asturias, Castanedo del Monte) preserved in the Natural History Museum, London. 1, Habitus, lateral view; 2, head dorsal view; 3, head frontal view; 4, head lateral view; 5, mesosoma, lateral view; 6 , tarsal claw (the numbers indicate the two tooth-like processes on inner margin); 7, wings. 
be distinguished by the shape and sculpture of the head (Figs. 2-4), the rounded anterior margin of the mesoscutum (Fig. 5) (acute, lamelliform and upwards directed in P. kostylevi), and the shape of the hind coxa (Turrisi, 2007).

Distribution. Algeria, Morocco, Greece, Turkey (Ferrière, 1933; Turrisi, 2007). New to Iberian Peninsula.

REMARKS. According to Ferrière (1933) the type material consists of four specimens, $2 \propto$ and $2 \hat{\gamma}$, all collected in Algerie (Babor), of which the holotype $q$ and one paratype $\delta \hat{~ a r e ~ p r e s e r v e d ~ i n ~ t h e ~ M u s e ́ u m ~ d ' H i s t o i r e ~ N a-~}$ turelle de Paris (France), both examined and revised by Turrisi (2007); the other two paratypes were not located by Ferrière (1933), but presumably they were kept in the collection of M.A. Barbey. It was previously known from only type locality, and recently recorded for Morocco, Europe (Greece), and Turkey (Turrisi, 2007). Based upon the present new record from Iberian Peninsula, this species shows a distribution covering the Southern Mediterranean area, although scattered and based on a relatively few records.

Very little is known on the biology of this species: the type specimens were obtained from wood of Abies numidica De Lannoy ex Carriére (Pinaceae) together with an unidentified Coleoptera Buprestidae
(Ferrière, 1933), whereas the Turkish specimens were obtained together with its potential host, Phaenops knoteki Reitter, 1898 (Coleoptera: Buprestidae) (Turrisi, 2007).

Based upon the present new record, the family Aulacidae in the Iberian Peninsula (including Canary Islands) is represented by a total of five species, all included within the genus Pristaulacus, the other previously recorded species being: $P$. compressus (Spinola, 1808), P. galitae (Gribodo, 1879), P. patrati (AudinetServille, 1833) and P. proximus Kieffer, 1906. However, the identity of the latter species is uncertain and still requires further investigations (type material not located, see Turrisi, 2007). The identification of the Iberian species of Aulacidae can be done using the key proposed by Turrisi (2007), more recently updated by Turrisi (2011).

\section{ACKNOWLEDGMENTS}

The author is grateful to Ms. Suzanne Ryder and Dr Gavin Broad (Natural History Museum, London) for their assistance during the revision of the Aulacidae stored in the Natural History Museum through the grant obtained by Turrisi G.F. under the European Commission's (FP 6) Integrated Infrastructure Initiative Programme Synthesys (GB-TAF 390). 


\section{REFERENCES}

Deyrup M.A., 1984 - A maple wood wasp, Xiphydria maculata, and its insect enemies (Hymenoptera: Xiphydriidae). The Great Lakes Entomologist, 17: 17-28.

FERrière C.H., 1933 - Un nouvel Aulacidae Nord-africain (Hym.). Bulletin de la Société Entomologique de France, 38: 140143.

Hedicke H., 1939 - Aulacidae. Hymenopterorum Catalogus, Pars 10. Verlag Gustav Feller, Neubrandenburg: 3-28.

Jennings J.T. \& Austin A.D., 2004 - Biology and host relationships of aulacid and gasteruptiid wasps (Hymenoptera: Evanioidea): a review. In: Rajmohana, K., SudheEr, K., Girish Kumar, P. \& Santhosh, S. (eds.), Perspectives on Biosystematics and Biodiversity: 187-215. University of Calicut, Kerala, India.

KIEFFER J.-J., 1912 - Hymenoptera, Ichneumonidea, Evaniidae. Das Tierreich. Verlag von R. Friedländer und Sohn, Berlin.

Skinner E.R. \& Thompson G.H., 1960 - The Alder woodwasp and its Insect Enemies. World Educational Films.

SмIth D.R., 2001 - World catalog of the family Aulacidae (Hymenoptera). Contributions on Entomology, International, 4(3): 261-319.

TURRISI G.F., 2004 - Revisione delle specie paleartiche del genere Pristaulacus Kieffer, 1900, con considerazioni filogenetiche e note sulla biologia. Ph.D. Thesis, University of Catania, 1-203.

Turrisi G.F., 2007 - Revision of the Palaearctic species of Pristaulacus Kieffer, 1900 (Hymenoptera: Aulacidae). Zootaxa, 1433: $1-76$.

TURRISI G.F., 2011 - Systematic revision of the sibling species belonging to the Pristaulacus compressus group (Hymenoptera: Aulacidae). Insect Systematics \& Evolution, 42: 1-27.

TURrisi G.F., JENNINGS J.T. \& VilHeLMSEN L., 2009 - Phylogeny and generic concepts of the parasitoid wasp family Aulacidae (Hymenoptera: Evanioidea). Invertebrate Systematics, 23: 27-59.

Turrisi G.F. \& Konishi K., 2011 - Description of two new Aulacidae (Hymenoptera: Evanioidea) from Japan. Zootaxa, 2872 : $35-48$.

Turrisi G.F. \& Watanabe K., 2011 - Description of two new Asian Pristaulacus Kieffer 1900 (Hymenoptera: Aulacidae). Zootaxa, 2895: 35-46.

Author's address:

Giuseppe Fabrizio Turrisi, via Cristoforo Colombo 8, 95030 Pedara (CA), Italy. E-mail: turrisifabrizio@yahoo.it 